\title{
Color (CIE L*, a*, b*), Nutritional and Sensory Characterization of Artisanal "Wagashi” Cheese Processed from Borgou and Azawak Cow Milks in Benin
}

\author{
Tougan P. Ulbad, ${ }^{1,2,3}$, Hongbete Franck ${ }^{1}$, Konate Adama ${ }^{4}$, Souho Tiatou ${ }^{5}$, Assa R. A. Rebecca ${ }^{6}$, Do- \\ mingo A. Ilonka ${ }^{1}$, Beckers Yves ${ }^{3}$, Sindic Marianne ${ }^{2}$, Thewis André ${ }^{3}$ \\ ${ }^{1}$ Department of Nutrition and Agro-Food Sciences, Faculty of Agronomy, University of Parakou, BP 123 Parakou, Republic of \\ Benin. \\ ${ }^{2}$ Laboratory “Quality and Agro-Food Security” of Gembloux Agro-Bio Tech, University of Liège, Passage des Déportés 2-5030 \\ Gembloux, Belgium. \\ ${ }^{3}$ Unit of Animal Production Engineering and Nutrition, Gembloux Agro-Bio Tech, University of Liège, Passage des Déportés \\ 2-5030 Gembloux, Belgium. \\ ${ }^{4}$ Department of Animal Husbandry, University of Sciences, Technics and Technologies, Bamako, Republic of Mali. \\ ${ }^{5}$ Faculty of Sciences and Technics, University of Kara, Kara, Kara Region, Republic of Togo. \\ ${ }^{6}$ Laboratory of the Unit of Biosciences, University Félix Houphouët Boigny of Cocody, Abidjan (Republic of Ivory Coast); 22 BP \\ 582 Abidjan 22, Abidjan, Republic of Ivory Coast.
}

How to cite this paper: Tougan P. Ulbad, Hongbete Franck, Konate Adama, Souho Tiatou, Assa R. A. Rebecca, Domingo A. Ilonka, Beckers Yves, Sindic Marianne, Thewis André. (2021) Color (CIE L*, a*, b*), Nutritional and Sensory Characterization of Artisanal "Wagashi" Cheese Processed from Borgou and Azawak Cow Milks in Benin. International Journal of Food Science and Agriculture, 5(3), 530-537.

DOI: $10.26855 / \mathrm{ijfsa} 2021.09 .025$

Received: August 5, 2021

Accepted: August 28, 2021

Published: September 10, 2021

*Corresponding author: Tougan P. Ulbad, Department of Nutrition and Agro-Food Sciences, Faculty of Agronomy, University of Parakou, BP 123 Parakou, Republic of Benin; Laboratory "Quality and Agro-Food Security” of Gembloux Agro-Bio Tech, University of Liège, Passage des Déportés 2-5030 Gembloux, Belgium; Unit of Animal Production Engineering and Nutrition, Gembloux Agro-Bio Tech, University of Liège, Passage des Déportés 2-5030 Gembloux, Belgium. Email: ulbad.tougan1@gmail.com

\section{Abstract}

The cattle herd of Benin includes several genotypes including Borgou and Azawak breeds. The study aimed to evaluate physicochemical characteristics and sensory attributes of artisanal cheeses processed with milks of Borgou and Azawak cow breeds reared on natural pasture at the breeding farm Okpara. So, 10 liters of fresh milk from each cow breed were collected for the production of cheese using artisanal cheese processing technology of Benin. Then, cheeses of both genetic types of cow milks were sampled for physic-chemical and sensory analyses. It appears that the luminance cheeses from Borgou cows is lower than that of Azawak cheeses (86.4 vs 89.2; $\mathrm{P}<0.01$ ). However, the values of red index, $\mathrm{pH}$, titratable acidity $\left({ }^{\circ} \mathrm{D}\right)$ and texture $(\mathrm{N})$ of the cheeses of the both genetic types were similar with the respective values of $-1.9,6.48$; 0.14 and 7.2 for Borgou breed and -1.85; 6.52; 0.13 and 6.8 for Azawak breed ( $\mathrm{P}>0.05)$. However, the yellow index $\left(\mathrm{b}^{*}\right)$ is 13.89 for Borgou cheeses to 12.6 for Azawak cheeses (P $<0.05)$. The hue $\left(\mathrm{H}^{*}\right)$ of cheese processed from Borgou cow milk was more important than the value recorded for Azawak cheese (-0.36 vs -2.75) while the higher chroma $\left(\mathrm{C}^{*}\right)$ value was obtained in cheese processed from Azawak cow milk (14.04 vs 12.74$)$. Nutritionally, the dry matter content (38.5\% vs $36.69 \%$; P $<0.001)$, fat content $(6.9 \%$ vs $4.65 \%$; $\mathrm{P}<0.001)$ and protein content $(8,89 \%$ vs. 8.28\%; $\mathrm{P}<0.05$ ) of Borgou cheeses were higher than those of Azawak cheeses. The ash content was 1.41 for Borgou cheeses to 2.3 for Azawak cheeses (P $<0.001)$. Organoleptic evaluation of both genetic type cows' cheeses showed that Borgou cheese had recorded the better scores for taste, texture, and overall acceptability. Traditional cheese processing technology may be promoted for food security in Benin. 


\section{Keywords}

Benin, breed effect, cheese quality, cow milk, food security

\section{Introduction}

The demand for dairy products in sub-Saharan Africa continues to increase with the overall growth rate in the consumption of milk and milk products including cheese, butter, being estimated at about $2.1 \%$ per annum [1, 2]. The growth in demand results from rapidly rising populations, urbanisation and some increase in per capita income. This increasing demand for milk and dairy products affords great opportunity and potential for the small holder milk producer and for the development of the milk production and processing industry.

In Republic of Benin, livestock sector includes 2,166,000 cattle, 1,716,000 goats; 860,000 sheep, 414,000 pigs and 181,980 poultry and represents $16.67 \%$ of agricultural GDP in 2013 [3]. The contribution of this livestock to food production in Benin is estimated at 23,431,000 tons of meat and offal; 12,522 tons of eggs and above all 107,310 tons of milk per year [3]. The milk production is supplied exclusively by indigenous cows breeds raised under traditional and semi-improved systems. It ensures a milk availability of 11.3 liters per year per capita for households. This milk availability remains below the minimum milk coverage standards of 62 liters recommended by FAO for developing countries. The main cattle breeds involved in the local milk production include zebus cattle (Yakanan, Goudali, M'Bororo and Djeli), and bull (N'Dama, Borgou, Somba and Lagunaire breeds). A large part of the cattle milk produced locally is used as raw materials in the artisanal cheese "Wagashi" processing.

The artisanal cheese wagashi of Benin is the result of a centennial Peuhl tradition passed down through the generations as a way to preserve the milk production of bovine bred on natural pasture in rural farms in the North of Benin. It is a great source of income and work for the considerable number of cattle producers in Benin. This artisanal cheese is a handmade product exclusively made with bovine milk. Cheese is a viscoelastic milk product formed by a net of casein with a dispersion of fat globules and water [4]. Several artisanal cheese production processes using vegetable extract or liquid rennet are documented [5, 6, 7, 8]. The Wagashi cheese processing technology in Benin is characterized by several stages: milk reception and filtering, temperature control, heating, coagulation by vegetable (Calotropis procera) leaves extract addition, cheese curd collection and molding, whey draining [5]. The use of Calotropis procera leaves extract as coagulant or rennet in artisanal cheese processing is reported by several authors [7, 8]. The obtained wagashi cheese is presented as circular mid-size product of the following dimensions: 10-15 cm (diameter) and 3-5 cm (height), approximately.

Several studies have been carried out on the production of milk by dietary supplement [9] or on lactogen plants [10] and the preservation of milk with essential oils [11]. Nevertheless, there is a lack of scientific data on the technological and nutritional properties of artisanal cheeses "Wagashi" processed from the different local breeds of cows milk in Benin. The aim of the work is to evaluate physicochemical characteristics, sensory attributes, texture and color parameters of artisanal cheese produced with milk of different local cow breeds (Borgou and Azawak).

\section{Materials and methods}

\subsection{Description of the study area}

The study was carried out sequentially at the Okpara livestock farm, the Faculty of Agonomy of the University of Parakou and the Laboratory "Quality and Safety of Agro-Food Products" of Gembloux Agro-Bio Tech, University of Liège in Belgium, from 1 May 2017 to 30 September 2020. The Opkara Livestock Farm is located in the Department Borgou, in the district of Tchaourou and in the village Kika ( $2^{\circ} 39-2^{\circ} 53$ East Longitude and $9^{\circ} 6-9^{\circ} 21$, North Latitude). The climate is of Sudanese type with an alternation of a rainy season (May to October) and a dry season (November to April). The annual average rainfall is of 1,125 mm recorded from 1994 to 2008 and the average annual temperature varies between $26^{\circ} \mathrm{C}$ and $27^{\circ} \mathrm{C}$.

\subsection{Cheese processing, sampling and data collection}

\subsubsection{Production of cheeses from Borgou and Azawak cow milks}

The raw milk was collected from fresh whole cow milk through hand milking from Borgou and Azawak cows reared on natural pasture in Okpara livestock farm, Benin. The production of cheese from Borgou and Azawak cow's Milk was made according to the artisanal cheese processing technology described by [5]. Ten liters of raw milk from each genetic type of cows at the third lactation rank were sampled under the same conditions at the end of milking on the same day. The samples of milk of each genetic type, cleaned from impurities, were heated at $70^{\circ} \mathrm{C}$ for about 10 minutes. 
Meanwhile, for each liter of milk processed, 2 of Callotropis Procera were crushed and the obtained extracts were used as a coagulant and were added before boiling. No rennet or starters were used and coagulation had taken about 30 minutes. Subsequently, coagulum was ladled into basket strainers to drain. The obtained curds from each genetic type were taken out of the basket without pressing or cutting and were used for the analyses.

\subsubsection{Evaluation of $\mathbf{p H}$ and titratable acidity of cheeses}

The $\mathrm{pH}$ and titratable acidity of the cheeses were determined on each sample according to the adapted method of the reference [12]. A calibrated $\mathrm{pH}$-meter (HANNA) was used to measure the $\mathrm{pH}$ in an aqueous suspension made of $10 \mathrm{~g}$ of cheese sample and $20 \mathrm{~mL}$ of distilled water. This suspension was then diluted with $70 \mathrm{~mL}$ of distilled water for determination titratable acidity by dose-titration with $\mathrm{NaOH} 0.05 \mathrm{~N}$. The acidity was estimated by the determination of the percentage of lactic acid.

\subsubsection{Color (CIE, $\mathrm{L}^{*} \mathrm{a}^{*} \mathbf{b}^{*}$ ) and texture analyses}

Color parameters were evaluated using a CR400 colorimeter, according to definitions proposed by the Commission Internationale de l'Éclairage [4, 13]. The value $L^{*}$ or luminosity indicates the product brightness or darkness and varies from 0 (black) to 100 (white). The value of $a^{*}$ (chromaticity coordinate) represents an indicator of green (-) and red (+). The value of $b^{*}$ is an indicator of blue (-) and yellow $(+)$. The hue values were calculated using $a^{*}$ and $b^{*}$ values according to the following formula: hue $=\tan ^{-1}\left(\mathrm{~b}^{*} / \mathrm{a}^{*}\right)$. Chroma $\left(\mathrm{C}^{*}\right)$ represents the color saturation. Chroma value was calculated according to the following formula: $\mathrm{C}^{*}=\left(\mathrm{a}^{* 2}+\mathrm{b}^{* 2}\right)^{1 / 2}$. The measurements were performed in duplicate, with the calibrated equipment, using 10 samples of each genetic type of cheese.

The texture analysis was evaluated using TA.XT Plus Texture analyzer (Lloyd Instrument), equipped with a cell charge of $25 \mathrm{~kg}$. Cylindrical uniform and homogeneous samples, with diameters and heights equal to $20 \mathrm{~mm}$, were removed from random points in the cheese samples. The sampled cheeses were kept at room temperature $\left(21^{\circ} \mathrm{C}\right)$ by genetic type. The texture value in Newton was obtained by a double compression test of the cheese cylinder, using a cylindrical compression probe of $75 \mathrm{~mm}$ diameter at a constant speed of $2.0 \mathrm{~mm} \mathrm{~s}^{-1}$. Ten independent replicates were produced for each type of cheese.

\subsubsection{Nutrient composition evaluation}

Overall, nutrient composition assessment was performed according to the standard procedures recommended by [14]. The moisture content was determined gravimetrically according to standard NF V 04-401 of April 2001 by kiln drying at $105^{\circ} \mathrm{C}$ until constant weight. The total mineral content was assessed by calcination in muffle furnace according to the standard NF V 04-2018 of October 1989 [4]. The cheese fat content was determined by the Mojonnier's method [4]. Determination of fat content in dry matter was made indirectly, by calculating the ratio between the fat content and the total solid content of the cheese. The total protein content was estimated by the Kjeldal method by using the standard NF V04-211 of December 1971. The factor used in conversion from nitrogen to total protein was 6.38. Analyses were performed in triplicates.

\subsubsection{Organoleptic evaluation}

Organoleptic evaluation of the samples of cheese was evaluated for sensory characteristics using 9 points' hedonic scale (9-Like Extremely, 8-Like Very Much, 7-Like Moderately, 6-Like Slightly, 5-Neither Like nor Dislike, 4-Dislike Slightly, 3-Dislike Moderately, 2-Dislike Very Much, 1-Dislike Extremely) and sensory score card [15]. Sensory evaluation was done by expert panel consisting of 20 members. The sensory attributes evaluated were: Taste, color, flavor, texture and overall acceptability

\subsection{Statistical analyses}

The data collected were submitted to analysis of variance (One Way-ANOVA) with SAS software [16]. The t-test was used to compare the means of the different cheese quality parameters recorded for the both genetic types. All analyses used a significance level of $5 \%(\mathrm{P}<0.05)$.

\section{Results}

\subsection{Effect of the breed on the technological parameters of the cheeses}

Table 1 shows the effect of the breed on the technological parameters of the cheeses. It appears that the luminance of cheese processed Borgou cow milk is significantly lower than that of cheeses processed from Azawak cow milk (86.4 vs 89.2; P0.01). However, the red index of cheese from milk of the both genetic types of cows is similar and ranges from -1.9 to -1.85 . Furthermore, the higher yellow index is found in cheeses of Borgou cows (13.89 vs 12.6; $\mathrm{P}<0.05$ ).

The $\mathrm{pH}$, titrable acidity $\left({ }^{\circ} \mathrm{D}\right)$ and instrumental texture $(\mathrm{N})$ values were also similar with the respective average values of 6.48; 0.14 and 7.2N for cheeses of Borgou cows breed and 6.52; 0.13 and 6.8 for cheeses of Azawak cows breed $(\mathrm{P}>0.05)$. 
Figure 1 presents the Hue and Chroma values for both genetic types of cheeses. It comes out from this figure that the hue value of cheese processed from Borgou cow milk was more important than the value recorded for Azawak cheese while the higher chroma value was obtained in cheese processed from Azawak cow milk. Hue indicates the color while Chroma $\left(\mathrm{C}^{*}\right)$ represents the color saturation.

Table 1. Variation of technological parameters of cheeses according to the cow breed

\begin{tabular}{|c|c|c|c|c|c|}
\hline \multirow[t]{2}{*}{ Variables } & \multicolumn{2}{|c|}{$\begin{array}{l}\text { Cheese processed from Borgou cow } \\
\text { milk }\end{array}$} & \multicolumn{2}{|c|}{$\begin{array}{l}\text { Cheese processed from Azawak cow } \\
\text { milk }\end{array}$} & \multirow[t]{2}{*}{$\begin{array}{l}\text { Effect of cow } \\
\text { breed }\end{array}$} \\
\hline & Mean & Standard Error & Mean & Standard Error & \\
\hline Luminance (L*) & 86.4 & 0.93 & 89.2 & 0.62 & $* *$ \\
\hline Red Index (a*) & -1.85 & 0.045 & -1.9 & 0.32 & NS \\
\hline Yellow Index (b*) & 13.89 & 0.51 & 12.6 & 0.42 & $*$ \\
\hline pH & 6.48 & 0.04 & 6.52 & 0.01 & NS \\
\hline Titratable Acidity $\left({ }^{\circ} \mathrm{D}\right)$ & 0.13 & 0.002 & 0.14 & 0.002 & NS \\
\hline Texture (N) & 7.2 & 0.35 & 6.8 & 0.48 & NS \\
\hline
\end{tabular}

NS: Non Significatif; *: $P<0.05 ; * *: P<0.01$.

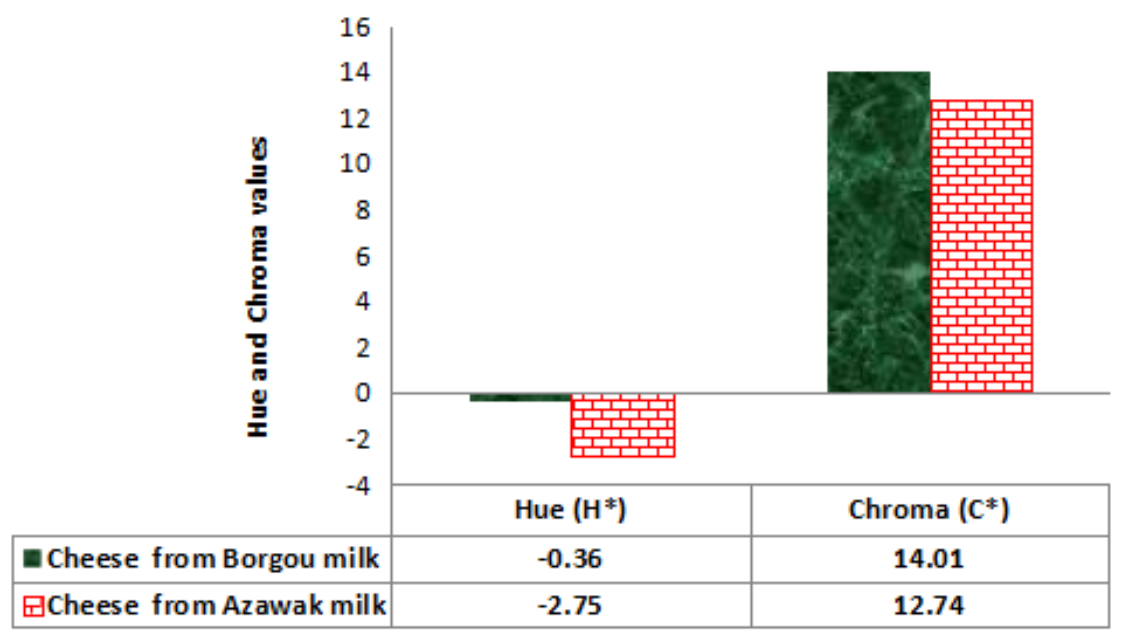

Figure 1. Hue and Chroma values of cheeses processed from Borgou and Azawak cow milks.

\subsection{Nutritional quality of cheeses made from Borgou and Azawak cow's milk}

Table 2 presents the variation of macronutrients contents of the cheeses processed from Borgou and Azawak cow's milk. It appears that the dry matter content of cheeses processed from Borgou cow milk is significantly higher than that of Azawak breed (38.5\% versus 36.69\%; $\mathrm{P}<0.001$ ). Similarly, the fat content of cheeses processed from Borgou cow milk is $6.9 \%$ to $4.65 \%$ for cheeses Azawak $\mathrm{P}<0.001$ ). Furtheremore, cheeses processed from Borgou cow milk are also richer in protein than those from Azawak cow's milk (8.89\% vs 8.28\%; $\mathrm{P}<0.05)$. On the other hand, the total mineral content is $1.41 \%$ for cheeses processed from Borgou cow milk to $2.3 \%$ for cheese processed from Azawak cow milk.

Table 2. Variation of macronutrients contents of cheese according to the local cows breed

\begin{tabular}{|c|c|c|c|c|c|}
\hline \multirow{2}{*}{ Variables } & \multicolumn{2}{|c|}{$\begin{array}{l}\text { Cheese processed from Borgou } \\
\text { cow milk }\end{array}$} & \multicolumn{2}{|c|}{$\begin{array}{l}\text { Cheese processed from Azawak cow } \\
\text { milk }\end{array}$} & \multirow{2}{*}{$\begin{array}{l}\text { Effect of cow } \\
\text { breed }\end{array}$} \\
\hline & Mean & Standard Error & Mean & Standard Error & \\
\hline Dry matter (g/100g) & 38.5 & 0.65 & 36.69 & 0.78 & $* * *$ \\
\hline Fat (g/100g) & 6.9 & 0.46 & 4.65 & 0.22 & $* * *$ \\
\hline Protein (g/100g) & 8.89 & 0.21 & 8.28 & 0.32 & $*$ \\
\hline Ash (g/100g) & 1.41 & 0.2 & 2.3 & 0.06 & $* * *$ \\
\hline
\end{tabular}

*: $P<0.05$; ***: $P<0.001$. 


\subsection{Sensory attributes cheeses made from milk of Borgou and Azawak cows breeds}

Figure 2 showed that there was a difference in the sensory attributes of wagashi cheeses processed from Borgou and Azawak bovine breeds milks. The sensory attributes measured are appearance, taste, flavor, color, texture and overall acceptability. According to Figure 2, there was a difference in the appearance of cheese with the higher value found in Azawak cheese. Appearance of a food product like cheese includes all its visible attributes and is the main consumer's only consideration when evaluating a food product. Taste is the primary factor which determines the acceptability of any food product. In the current study, the cheese processed from Borgou cow milk had recorded the best taste score.

Flavor is the sensory impression of a food, and is determined by mainly by the senses of taste and smell. According to Figure 2, there was a difference in the flavor score of cheese with the highest value found in Azawak cheese. An attractive color leads to the good demand for the food product in the market. In our study, the color acceptability score of the cheese Azawak was of 7.5 to 7 for the cheese Borgou.

Texture is defined as the property of a food that is sensed in touch in the mouth and with the hands. The cheese of Borgou cow's breed had the highest mean value. Overall acceptability is an important parameter in sensory evaluation. Organoleptic evaluation of both genetic type cows' cheeses showed that Borgou cheese had recorded the better score for Overall acceptability (Figure 2). The study established that the genotype of cow can affect the sensory quality of cheese.

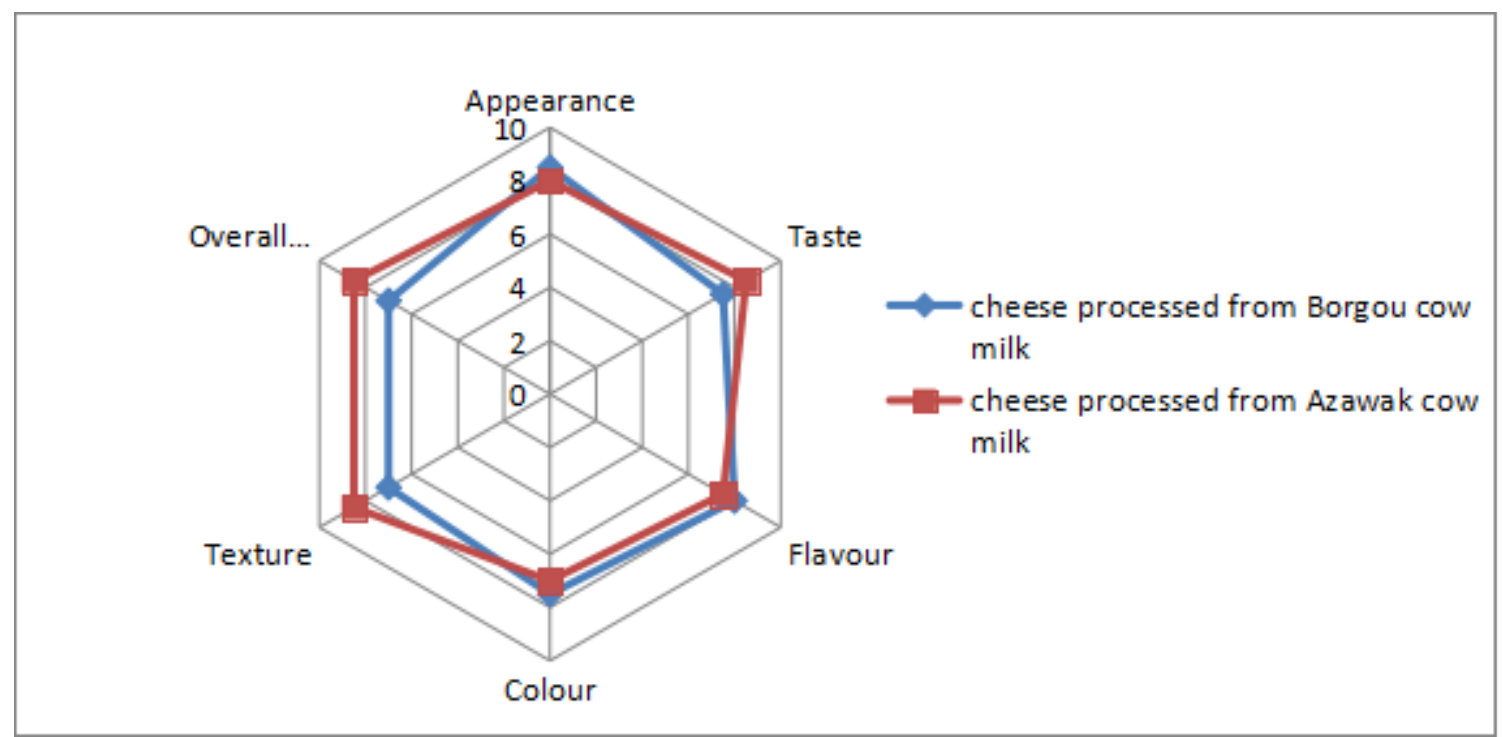

Figure 2. Mean scores of sensory acceptability test of artisanal "Wagashi” cheese processed from Borgou and Azawak cow milks.

\section{Discussion}

\subsection{Effects of cow breed on the technological quality of cheese}

The present study shows that cheeses processed from Borgou cow milk are darker with the higher yellow index than those processed from Azawak cow milk. This variability of the trichromatic color (CIE, Lab) of the cheeses may be related to the genetic variability of the physico-chemical composition of the milk of the cows involved in the study. Indeed, the work of [17] on cheese and butter processing aptitudes and nutritional values of local cow's milk reared on natural pasture revealed that significant differences exist in the physicochemical traits and nutrient composition of indigenous cow's milk according to genetic type. Indeed, according to these authors, Borgou cow milk had recorded the highest fat content ant the lower protein concentration compared to Azawak breed milk [17]. The $\mathrm{pH}$ and titratable acidity recorded herein are in accordance with the ranges of the values reported by [5] for $\mathrm{pH}$, and titratable acidity for cheese but lower than the values reported by $[6,18]$.

The slight difference found in the texture of cheese could be due to the genetic variants in the physico-chemical composition of the samples of milk involved in the study for cheese processing. According to [19], the texture of milk curd is genetically correlated with protein and casein contents of bovine milk. Furthermore, [19] indicated that the fat content of ewe's milk was positively associated with cheese firmness.

The difference found for the texture of cheese may be due to the difference in their fat content. When there is a reduction of cheese fat content, the microstructure of the protein net is changed. The hardness and elasticity of cheese increase, while adhesiveness and cohesiveness decrease with the reduction of fat content [20]. On the other hand, 
cheeses with high fat content are characterized by attributes such as more softness, cohesiveness and good flavor.

\subsection{Effects of cow breed on the macronutrients contents of cheese}

Nutrients contents of "wagashi" cheese are some relevant variables which are influenced by different factors such as milk quality and cheese-making methods and raw materials [21, 22, 23, 24]. Our results showed that there was a significant difference in the macronutrients contents of cheeses processed from Borgou and Azawak cow milks. Indeed, the higher contents in dry matter, protein and fat were found in Borgou cheese while the most important ash content was observed in Azawak breed. In our study, "Wagashi" cheese processing technology, cow rearing system, milking period, cow calving rank, and season of the milking are the same. Therefore, the observed differences may be due to the genetic type of the cows involved in the study. This observed effect of cow breed on cheese quality was also reported by [25], [26], [27] and [22]. According to the literature, different factors can produce difference in the physic-chemical composition of cheese, including those related to the cow genetic diversity, milk composition and quality, season, microbial count and diversity, and cheese processing technology [28, 29, 30, 31]. The higher moisture in cheese processed from Azawak cow milk may be explained by the lower content of fat present in Azawak cow milk. This result is according to reports by [21] that also reported in their studies an increase in the moisture as the fat rate was reduced.

\subsection{Effects of cow breed on the sensory attributes of cheese}

The scores recorded for sensory acceptance for the artisanal cheeses tested herein are better than the scores reported by [33] for fresh cheese from raw cow milk. Moreover, from literature, goat and sheep cheese are not preferred by large part of population which do not appreciate a strong goaty or sheepy aroma, even though they are not very familiar with these aromas [33]. In the same way, [34] have compared the acceptance of fermented milk of cow and goat. Their results have indicated that fermented cow's milk had been well accepted compared to fermented goat's milk. Cheese is a visco-elastic material formed by a net of casein where dispersed globules of fat and water determine its texture [35]. The texture is identified by consumers as one of the most important attributes of cheese quality [36] and the most important sensorial characteristics, because it allows the consumer to identify specific varieties and their qualities, even before evaluating the flavor [37].The cheese texture is influenced by several factors, one of the most relevant factors being the raw-material composition [37] and changes on these parameters are caused by contents of protein, water, $\mathrm{pH}$ and fat, in this order [38]. Furthermore, color parameters acting as a differential in characterization of different types of cheese [39, 40, 4, 41].

Overall, the development of a milk values chains in Benin, taking into account the intrinsic value of cheese made from indigenous cattle breed milk, could be an important opportunity for food security and cattle genetic resources conservation [42].

\section{Conclusion}

From this study, it appears that the quality of "wagashi" cheese depends on the genetic type of the dairy cow. Cheese processed from Borgou cow milk is more yellow, less white, and firmer than cheese made from Azawak cow milk. Furthermore, cheese processed from Borgou cow milk is richer dry matter, protein and fat, but poorer in minerals, than cheese made from Azawak cow milk. The development of an indigenous cattle breed milk values chains could be an important opportunity for food security in Benin.

\section{Acknowledgement}

The authors gratefully thank the University of Parakou for competitive research fund, the University of Liege for technical support and ARES-CCD of Belgium for research grant. They also thank the Responsible of the National cattle breeding farm of Okpara and their artisanal cheese producers for technical help with milk collection and the cheese processing.

\section{Conflicts of interest}

The authors declare that they have no conflict of interests.

\section{References}

[1] O’Connor, C. (1993). Traditional cheese making manual, ILCA, (International Livestock Centre for Africa), Addis Ababa, Ethiopia, 1-24.

[2] FAO. (2020). The State of Food Insecurity in the World. Rome: FAO; 76pp.

[3] CountryStat/Benin. (2012). Statistics database. http://countrystat.org/ben; http://www.fao.org/economic/ess/ countrystat/en/. 
[4] Pathare, B. P., Opara, U. L., and Al-Said, F. A. J. (2012). Color Measurement and Analysis in Fresh and Processed Foods: A Review, Food Bioprocess Technology (on line). http://link.springer.com/article/10.1007\%2Fs11947-012-0867-9\#page-1.

[5] Dossou, J., Montcho, J. K., Londji, S., Atchouké, G. D. L., and Odjo, S. (2016). Improved process for preserving and stabilizing Peuhl cheese through the combined effect of heat treatment and vacuum packaging. European Scientific Journal, vol. 12, No. 36. ISSN: 1857-7881. URL:http://dx.doi.org/10.19044/esj.2016.v12n36p189.

[6] Ariceaga, C. C. G., Afzal, M. I., Umer, M., Abbas, S., Ahmad, H., Sajjad, M., Parvaiz, F., Imdad, K., Imran, M., Maan, A. A., Khan, M. K. I., Ullah, A., Hernández-Montes, A., Aguirre-Mandujano, E., de Gante, A. V., Jacquot, M., and Cailliez-Grimal, C. (2019). Physicochemical, Sensorial and Microbiological Characterization of PoroCheese, an Artisanal Mexican Cheese Made from Raw Milk. Foods, 2019, 8, 509. doi: 10.3390/foods8100509.

[7] Omotoso, O. E., Oboh, G. and Iweala, E. E. J. (2011). Comparative effects of local coagulants on the nutritional value, in vitro multienzyme protein digestibility and sensory properties of wara cheese. International Journal of Dairy Sciences, 6(1), 58-65.

[8] Akinloye, A. M. and Adewumi, O. O. (2014). Effects of local coagulants on the yield of cheese using cow and sheep milk. International Journal of Development and Sustainability, 3(1), 150-161.

[9] Senou, M., Toléba, S. S., Adandédjan, C., Poivey, J.-P., Ahissou, A., Touré, F. Z., and Monsia, C. (2008). Increased Milk Yield in Borgou Cows in Alternative Feeding Systems. Revue Elev. Méd. Vét. pays Trop., 61(2): 109-114.

[10] Chabi Toko, L., Toléba, S. S., and Dahouda, M. (2010). Cottonseed meal and Vitellariaparadoxa leaves supplementation of Borgou cows in rainy season. International Journal of Biological and Chemical Science, 2, 555-559.

[11] Sessou, P., Farougou, S., Azokpota, P., Youssao, A. K. I., Fanou, B., Kaneho, S., Agniwo, B., Yèhouenou, B., Ahounou, G. S., Chabi-Egba, M., and Sohounhloué, D. (2013). In vitro antifungal activity of essential oil of Pimenta racemosa against fungal isolates from wagashi, a traditional cheese produced in Benin. International Journal of Natural and Applied Sciences, 8(1): 25-34. ISSN: 0794-4713.

[12] Isildak, I. and Gones, A. G. (2018). Simultaneous SIA analysis of pH and total acidity measurements in milk. Food Measure, 12, 403-411. https://doi.org/10.1007/s11694-017-9653-8.

[13] Tougan, P. U., Bonou, A. G., Gbaguidi, T., Koutinhouin, G. B., Ahounou, S., Salifou, C. F. A., Zannou, M. S., Mensah, G. A., Beckers, Y., Everaert, N., Théwis, A., and Youssao, A. K. I. (2016). Influence of Feed Withdrawal Length on Carcass Traits and Technological Quality of Indigenous Chicken Meat Reared Under Traditional System in Benin. Journal of World’s Poultry Research, 6(2): 37-47.

[14] A.O.A.C. (2000). Official Methods of Analysis. Hornitz. W. Ed. Washington, Association of Official Analytical Chemists. 16th ed. Washington, D.C., U.S.A.

[15] Amerine, M. A., Pangborn, R. M., and Rosseler, E. B. (1965). In principles of sensory evaluation of food. Academic Press: New York.

[16] SAS. (2006). SAS/STAT User’s guide, vers, 6, 4th ed, Cary, NC, USA, SAS Inst.

[17] Tougan, P. U., Daouda, I. H., Djenontin, J. A., Gouwakinnou, G., Adakamou, S. G. T., Mekpo, L. A., Mensah, G. A., Koutinhouin, G. B., Beckers, Y., Sindic, M., and Thewis, A. (2018). Cheese-making and butter-making qualities and technological properties of milk of Borgou and Azawak cows reared on natural pasture in Benin. Bulletin de la Recherche Agronomique du Bénin (BRAB), Special issue Livestock \& Wildlife - December 2018. BRAB on lineat. http://www.slire.net; ISSN sur papier (on hard copy): 1025-2355 et ISSN en ligne (on line): 1840-7099.

[18] Aworth, O. C. and Muller, H. G. (1987). Cheese-making properties of vegetable rennet from sodom apple (Calotropis procera). Food Chemistry, 26(1), 71-79.

[19] Bittante, G., Cipolat-Gotet, C., Pazzola, M., Dettori, M. L., Vacca, G. M., and Cecchinato, A. (2016). Genetic analysis of coagulation properties, curd firming modeling, milk yield, composition, and acidity in Sarda dairy sheep. J. Dairy Sci., 100: 385-394. https://doi.org/10.3168/jds.2016-11212.

[20] Karahan, A. G., Kart, A., Akoğlu, A., and Çakmakç, M. L. (2011). Physicochemical properties of low-fat soft cheese Turkish Beyaz made with bacterial cellulose as fat mimetic. International Journal of Dairy Technology, 64(4), 502-508.

[21] Souza, V. R., Carneiro, J. D. S, Pinto, S. M., Souza, A. B., and Stephani, R. (2012). Effect of fat concentration on the physical, chemical and sensory properties of "petit Suisse" cheese prepared with whey retention. Journal of the Dairy Institute of Cândido Tostes, 67(386), 2012, 20-28.

[22] Boudalia, S., Boudebbouz, A., Gueroui, Y., Bousbia, A., Benada, M., Leksir, C., Boukaabene, Z., Saihi, A., Touaimia, H., Aït-Kaddour, A., and Chemmam, M. (2020). Characterization of traditional Algerian cheese "Bouhezza” prepared with raw cow, goat and sheep milks. Food Science and Technology, Campinas, 40(Suppl. 2): 528-537.

[23] Silanikove, N., Leitner, G., and Merin, U. (2016). Influence of animal health, breed, and diet on non-cow milk composition. In E. Tsakalidou and K. Papadimitriou (Eds.), Non-bovine milk and milk products (Chap. 4, pp. 61-79). San Diego: Academic Press. http://dx.doi.org/10.1016/B978-0-12-803361-6.00004-1.

[24] Ruvalcaba-Gómez, J. M., Ruiz-Espinosa, H., Arteaga-Garibay, R. I., Rojas-López, M., Amador-Espejo, G. G., Anaya-Esparza, L. M., and Delgado-Macuil, R. J. (2020). Texture, physicochemical and sensory properties of artisanal Adobera cheese from Los Altos de Jalisco, a genuine Mexican cheese. International Journal of Dairy Technology, 73(2), 411-420. 
http://dx.doi.org/10.1111/1471-0307.12676.

[25] Mallatou, H. and Pappa, E. (2005). Comparison of the characteristics of teleme cheese made from ewe's, goat's and cow's milk or a mixture of ewe's and goat's milk. International Journal of Dairy Technology, 58(3), 158-163. http://dx.doi.org/10.1111/j.1471-0307.2005.00204.x.

[26] Rasheed, S., Qazi, I. M., Ahmed, I., Durrani, Y., and Azmat, Z. (2016). Comparative study of cottage cheese prepared from various sources of milk. Proceedings of the Pakistan Academy of Sciences: Pakistan Academy of Sciences B, Life and Environmental Sciences, 53(4), 269-282.

[27] Hamidi, M., Hachi, M., Lahrech, A., and Choukri, A. (2018). Cheese production by kaolin extract from chicken gizzard with milk from cows, sheep or goats in the Algerian steppe. Livestock Research for Rural Development, 30(11). Retrieved from http://www.lrrd.org/lrrd30/11/med.h30192.html.

[28] Verdier-Metz, I., Coulon, J.-B., and Pradel, P. (2001). Relationship between milk fat and protein contents and cheese yield. Animal Research, 50(5), 365-371. http://dx.doi.org/10.1051/animres:2001138.

[29] Simões, M. G., Rabelo, J. G., Portal R. E., Domingues, A. F. N., Oliveira, E. B., and de Luces Fortes Ferreira, C. L. (2013). Physicochemical properties of Butter cheese from Marajó manufactured with buffalo milk and cow milk. IOSR Journal Of Environmental Science, Toxicology And Food Technology (IOSR-JESTFT) e-ISSN: 2319-2402, p-ISSN: 2319-2399. Volume 5, Issue 3 (Jul.-Aug. 2013), pp. 83-88; www.Iosrjournals.Org.

[30] Sánchez-Gamboa, C., Hicks-Pérez, L., Gutiérrez-Méndez, N., Heredia, N., García, S., and Nevárez-Moorillón, G. V. (2018). Seasonal influence on the microbial profile of Chihuahua cheese manufactured from raw milk. International Journal of Dairy Technology, 71(S1), 81-89. http://dx.doi.org/10.1111/1471-0307.12423.

[31] Vladimír, D., Miloslava, K., Markéta, M., Jaroslava, H., and Petr, R. (2020). Microbial diversity of Livanjski cheese with the emphasis on lactic acid bacteria based on culture-dependent and sequencing method. International Journal of Dairy Technology, 73(1), 202-214. http://dx.doi.org/10.1111/1471-0307.12638.

[32] Dal Bello, B., Torri, L., Piochi, M., Bertolino, M., and Zeppa, G. (2017). Fresh cheese as a vehicle for polyunsaturated fatty acids integration: effect on physico-chemical, microbiological and sensory characteristics. International Journal of Food Sciences and Nutrition, 68(7), 800-810. http://dx.doi.org/10.1080/09637486.2017.1301891. PMid: 28320208.

[33] Ryffel, S., Piccinali, P., and Bütikofer, U. (2008). Sensory descriptive analysis and consumer acceptability of selected Swiss goat and sheep cheeses. Small Ruminant Research, 79(1), 80-86. http://dx.doi.org/10.1016/j.smallrumres.

[34] Costa, M. P., Balthazar, C. F., Rodrigues, B. L., Lazaro, C. A., Silva, A. C. O., Cruz, A. G., and Conte Junior, C. A. (2015). Determination of biogenic amines by high-performance liquid chromatography (HPLC-DAD) in probiotic cow's and goat's fermented milks and acceptance. Food Science and Nutrition, 3(3), 172-178. http://dx.doi.org/10.1002/fsn3.200. PMid: 25987991.

[35] Prentice, J. H., Langley, K. R., and Marshall, R. J. (1993). Cheese Rheology, in: Cheese: Chemistry, Physics and Microbiology (Fox PF et al., editor: Chapman and Hall, 1993).

[36] Jack, F. R., Paterson, A., and Piggot, J. R. (1993). Relationships between rheology and composition of Cheddar cheeses and texture as perceived by consumers. International Journal of Food Science and Technology, 28, 293-302.

[37] Fox, P. F., Guinee, T. P., Cogan T. M., and Mc Sweeney, P. L. H. (2000). Cheese rheology and texture, in: Fundamentals of cheese science (Fox P.F. et al., editor: Aspen Publisher Inc, 2000).

[38] Chen, A. H., Larkin, J. W., Clark, C. J., and Irwin, W. E. (1979). Textural analysis of cheese. Journal of Dairy Science, 62, 1979, 901-907.

[39] Van Hekken, D. L., Tunick, M. H., Tomasula, P. M., Corral, F. J. M., Gardea, A. A., and Chihuahua, M. Q. (2007). Rheology of fresh cheese. Int. J. Dairy Technol., 2007, 60, 5-12.

[40] Vasek, O. M., Leblanc, J. G., Fusco, A., and De Giori, G. S. (2008). Chemical composition and microbial evaluation of Argentinean Corrientes cheese. Int. J. Dairy Technol., 2008, 61, 222-228.

[41] Ramirez-Rivera, E. D. J., Juarez-Barrientos, J. M., Rodriguez-Miranda, J., Diaz-Rivera, P., Ramon-Canul, L. G., Herrera-Corredor, J. A., Hernandez-Serrano, M. I., and Herman-Lara, E. (2017). Typification of a fresh goat cheese of Mexico by path models. Turk. J. Vet. Anim. Sci., 41, 213-220.

[42] Cassandro, M., Chiara Dalvit, E., Zanetti, M., De Marchi, R., and Dal, Z. (2008). Genetic aspects of milk coagulation properties in dairy cattle: Review paper. ISSN 1330-7142. 